\title{
First Amendment Limitations On Patronage Employment Practices
}

In the landmark case of Elrod $v$. Burns, ${ }^{1}$ the Supreme Court for the first time addressed the constitutionality of political patronage employment practices. ${ }^{2}$ The Court ruled that dismissals of public employees based on their political affiliations inhibit the exercise of their protected first amendment rights of belief and association and held that patronage dismissals therefore place an unconstitutional condition on public employment. ${ }^{3}$ The Court exempted employees in policymaking and confidential positions from its ruling, however." Four years later, Branti v. Finkel reaffirmed the prohibition of patronage firings and narrowed the scope of positions exempt from that proscription. ${ }^{\circ}$

Elrod and Branti declined to address the constitutionality of other patronage personnel actions such as hirings, transfers, reassignments, demotions, and failures to promote. The decisions by lower courts addressing these practices are cryptic and inconsistent. ${ }^{8}$ This comment argues that all adverse personnel actions taken because of an employee's political affiliation are unconstitutional. To confine the Elrod-Branti doctrine to practices that are the substantial equivalent of dismissal, as the Fourth Circuit has

1427 U.S. 347 (1976).

2 Patronage has been defined as the "allocation of the discretionary favors of government in exchange for political support." M. \& S. Tolchin, To The VicTor 5 (1971). The Supreme Court previously had considered the constitutionality of legislative proscriptions against patronage. See United States Civil Serv. Comm'n v. National Ass'n of Letter Carriers, 413 U.S. 548 (1973) (holding Hatch Act restrictions on political activities of government employees constitutional); United Public Workers v. Mitchell, 330 U.S. 75 (1947) (holding the Hatch Act constitutional); Ex parte Curtis, 106 U.S. 371 (1882) (holding constitutional a statute that forbade certain forms of political contribution by public employees).

327 U.S. at 373.

Id. at 367-68.

- 445 U.S. 507 (1980).

- Id. at 518; see text and notes at notes 39-56 infra.

7 Branti v. Finkel, 445 U.S. 507, 513 n.7 (1980); Elrod v. Burns, 427 U.S. 347, 353 (1976). For commentary on this issue, see Comment, Patronage and the First Amendment After Elrod v. Burns, 78 Colum. L. Rev. 468, 473-78 (1978) [hereinafter cited as Columbia Comment]; Comment, Political Patronage and the Fourth Circuit's Test of Dischargeability After Elrod v. Burns, 15 Wake Forest L. Rev. 655, 666-67 (1979).

- See cases cited infra notes 59-60. 
done, ${ }^{9}$ allows the prevailing political party to circumvent the principles underlying Elrod and Branti and is inconsistent with the traditionally high degree of protection accorded to the first amendment rights of belief and association.

\section{Patronage Dismissals}

\section{A. Elrod v. Burns}

In late 1970, after Democrat Richard Elrod was elected Sheriff of Cook County, Illinois, Republican noncivil service employees ${ }^{10}$ of the sheriff's office were dismissed for failure to affiliate with or obtain sponsorship by the Democratic Party. ${ }^{11}$ Several of the affected employees ${ }^{12}$ brought suit against Sheriff Elrod, ${ }^{13}$ contending that his actions violated their rights under the first and fourteenth amendments. The district court dismissed the complaint for failure to state a valid cause of action; the Seventh Circuit reversed. ${ }^{14}$

A divided Supreme Court affirmed the Seventh Circuit, holding that the patronage dismissals impermissibly infringed on the plaintiffs' rights of political association. ${ }^{15}$ Justice Brennan's plural-

${ }^{8}$ Delong v. United States, 621 F.2d 618, 624 (4th Cir. 1980). See text and notes at notes 65-77 infra.

${ }^{10}$ Such individuals are not covered by any statute, ordinance or regulation protecting them from arbitrary discharge or entitling them to such procedural safeguards as notice and a hearing. Elrod v. Burns, 427 U.S. 347, 350 (1976).

11 Certain employees merely were threatened with dismissal. Id. at 377. To acquire the sponsorship necessary to retain their positions, the plaintiffs were required to pledge their political allegiance to the Democratic Party, work for the election of Democratic candidates, and contribute, a portion of their wages to party coffers. Id. at 355.

${ }_{12}$ Plaintiffs included the Chief Deputy of the Process Division, a process server, a bailiff-security guard, and an office worker. Id. at 351.

${ }^{13}$ Mayor Richard J. Daley, the Democratic Organization of Cook County, and the Democratic County Central Committee of Cook County also were named as defendants. Id. at 350.

14 Burns v. Elrod, 509 F.2d 1133 (7th Cir. 1975), aff'd, 427 U.S. 347 (1976). The Seventh Circuit's decision was based on Illinois State Employees Council 34 v. Lewis, 473 F.2d 561 (7th Cir. 1972), cert. denied, 410 U.S. 928 (1973), a case involving allegations nearly identical to those in Elrod and the first federal case to hold that patronage dismissals violate public employees' first amendment rights.

1s Elrod v. Burns, 427 U.S. 347, 373 (1976); id. at 375 (Stewart, J., concurring). Justice Brennan wrote the plurality opinion, in which Justices White and Marshall joined. Justice Stewart, joined by Justice Blackmun, filed an opinion concurring in the judgment. Chief Justice Burger filed a dissenting opinion, and Justice Powell filed another dissent joined by the Chief Justice and Justice Rehnquist. Justice Stevens took no part in the consideration of the case.

The Court rejected the defendant's argument that the political question doctrine and separation of powers principles precluded judicial consideration of patronage dismissals. Id. at 351-53; see id. at 377 n.1 (Powell, J., dissenting). Chief Justice Burger, however, objected 
ity opinion emphasized that freedom of political association is at the core of rights protected by the first amendment ${ }^{16}$ and argued that when public employees are required to pledge allegiance to a political party, the inevitable result is the coercion of their true beliefs. ${ }^{17}$ Justice Brennan found this coercion to be in conflict with the long-standing principle condemning governmental use of sanctions and benefits to "prescribe what shall be orthodox in politics." "18

Relying on Keyishian v. Board of Regents ${ }^{19}$ and Perry $v$. Sindermann, ${ }^{20}$ both extending the first amendment rights of public employees, the plurality opinion also argued that linking government employment to partisan affiliation effectively imposed an unconstitutional condition on the receipt of a public benefit. ${ }^{21}$ The

to what he perceived as judicial intrusion into legislative policy concerns. Id. at 375-76 (Burger, C.J., dissenting).

The Elrod decision is analyzed in Columbia Comment, supra note 7; Comment, $\mathrm{Pa}$ tronage Dismissals and Compelling State Interests: Can the Policymaking/Nonpolicymaking Distinction Withstand Strict Scrutiny?, 1978 S. ILL. L.J. 278; Casenote, 18 B.C. INDus. \& Coм. L. REv. 782 (1977); Note, The Unconstitutionality of Patronage Dismissals of Public Employees: Elrod v. Burns, 427 U.S. 347 (1976), 9 CoNs. L. REv. 678 (1977); Note, Will the Victor Be Denied the Spoils? Constitutional Challenges to Patronage Dismissals, 4 Hastings Const. L.Q. 165 (1977); Note, Elrod v. Burns: Chipping at the Iceberg of Political Patronage, 34 WASH. \& LEE L. REv. 225 (1977).

${ }^{16} 427$ U.S. at 356. See generally Buckley v. Valeo, 424 U.S. 1, 15 (1976) (per curiam); Kusper v. Pontikes, 414 U.S. 51, 56-57 (1973); Bates v. City of Little Rock, 361 U.S. 516, 522-23 (1960); NAACP v. Alabama ex. rel. Patterson, 357 U.S. 449, 460-61 (1958).

17427 U.S. at $355-56$.

${ }^{18}$ Id. at 356 (quoting West Va. State Bd. of Educ. v. Barnette, 319 U.S. 624, 642 (1943)). In Barnette, the Court declared that "[if] there is any fixed star in our constitutional constellation, it is that no official, high or petty, can prescribe what shall be orthodox in politics, nationalism, religion, or other matters of opinion or force citizens to confess by word or act their faith therein." 319 U.S. at 642.

19385 U.S. 589 (1967). The Court in Keyishian invalidated several New York statutes barring individuals from state employment because of their membership in "subversive" organizations. Id. at 609-10.

${ }^{20} 408$ U.S. 593 (1972). In Perry, the Court reaffirmed the principle that a public school teacher may not be fired for exercising first amendment rights. Id. at 598. It also held that a teacher in a state college system could have a property interest in his job, $i d$. at 596-98, and therefore might be entitled to a hearing under the fourteenth amendment before he could be dismissed, $i d$. at 599-603.

${ }^{21} 427$ U.S. at 359 . The Court explicitly reaffirmed its rejection of the "privilege" doctrine under which public employment had been viewed as a privilege that could be denied for any reason. That doctrine had been advanced in such cases as Bailey v. Richardson, 182 F.2d 46 (D.C. Cir. 1950), aff'd, 341 U.S. 918 (1951) (per curiam), and McAuliffe v. Mayor of New Bedford, 155 Mass. 216, 29 N.E. 517 (1892) (Holmes, J.).

Perry outlined the doctrine of unconstitutional conditions:

[E]ven though a person has no "right" to a valuable governmental benefit and even though the government may deny him that benefit for any number of reasons, there are 
plurality reasoned that the condition inhibited association by threatening dismissal and penalized it by actual dismissal. ${ }^{22}$

The plurality next applied a balancing analysis to determine whether the suspect character of patronage dismissals was outweighed by a compelling state interest; Elrod's actions were permissible only if they "further[ed] some vital government end by a means that [was] least restrictive of freedom of belief and association in achieving that end, and [if] the benefit gained . . . outweigh[ed] the loss of constitutionally protected rights."2s Elrod argued that patronage dismissals advanced governmental efficiency because employees sympathetic to the party out of power were likely to lack the incentive to work diligently. ${ }^{24}$ The plurality rejected this assumption as improper. ${ }^{25}$

some reasons upon which the government may not rely. It may not deny a benefit to a person on a basis that infringes his constitutionally protected interests-especially, his interest in freedom of speech. For if the government could deny a benefit to a person because of his constitutionally protected speech or associations, his exercise of those freedoms would in effect be penalized and inhibited.

408 U.S. at 597. Although the government generally may not condition public employment on an individual's sacrifice of his constitutional rights, it may attach certain conditions to particular positions, provided they are necessary to advance a compelling state interest. See, e.g., United States Civil Serv. Comm'n v. National Ass'n of Letter Carriers, 413 U.S. 548, 564-67 (1973); United Public Workers v. Mitchell, 330 U.S. 75, 95-103 (1947). See generally United States v. Marchetti, 466 F.2d 1309, 1313-15 (4th Cir.) (upholding injunction enforcing secrecy agreement between the CIA and one of its employees, entered into as a condition of employment), cert. denied, 409 U.S. 1063 (1972).

The complainant need not show that the government explicitly conditioned the receipt of a public benefit on the relinquishment of a constitutional right. Rather, he must show that the government withheld the benefit on the basis of some consideration that forced him to choose between the government benefit and his exercise of a protected activity. See, e.g., Sherbert v. Verner, 374 U.S. 398, 404 (1963) (denial of unemployment compensation based on plaintiff's refusal to work on Saturdays, in accordance with the practice of her religion, violates the first amendment). See generally French, Unconstitutional Conditions: An Analysis, 50 GEo. L.J. 234 (1961); Van Alstyne, The Constitutional Rights of Public Employees: A Comment on the Inappropriate Uses of an Old Analogy, 16 U.C.L.A. L. REv. 751 (1969); Van Alstyne, The Demise of the Right-Privilege Distinction in Constitutional Law, 81 Harv. L. REv. 1439 (1968); Note, Another Look at Unconstitutional Conditions, 117 U. PA. L. REv. 144 (1968).

22427 U.S. at 359.

${ }^{23}$ Id. at 363 . Employing this balancing test, the Court previously had sustained restrictions on first amendment activities of public employees imposed by section 9(a) of the Hatch Act, 5 U.S.C. $\$ 7324(a)(2)$ (1976), in United States Civil Serv. Comm'n v. National Ass'n of Letter Carriers, 413 U.S. 548 (1973).

24427 U.S. at 364.

${ }^{28}$ Id. The plurality also offered several countervailing considerations. First was the likelihood that inefficiency would result from the wholesale replacement of a large number of public employees every time there was a change of administration. Id. Second, the Court viewed the employees' uncertainty about their future after an election as a disincentive to 
Elrod also argued that patronage dismissals were necessary to ensure that the incumbent administration's policies would not be undercut by employees who could not give them their full support. ${ }^{26}$ The plurality found that permitting political dismissals of individuals in policy-making positions is sufficient to achieve this end, arguing that nonpolicymakers are in no position to thwart party goals. ${ }^{27}$

Elrod contended finally that patronage is crucial to the preservation of democratic government because of the support it generates for political parties. ${ }^{28}$ Justice Powell in dissent found this argument compelling, reasoning that patronage stimulates political activity by furnishing parties with incentives to attract labor and financing and that such incentives strengthen the democratic system by avoiding political fragmentation. ${ }^{29}$ The plurality found it unnecessary to consider the importance of a stable party system, for it was not convinced that barring patronage dismissals would "bring about the demise of party politics." port for this conclusion, however, holding simply that the gains to representative democracy were outweighed by the infringement of first amendment rights. ${ }^{31}$

Although its holding was limited to patronage dismissals, ${ }^{32}$ the plurality's condemnation of the patronage system was cast in

individual productivity. Id. Finally, because replacement of employees would not necessarily be based on merit or experience, there was no guarantee that the new employees would be more qualified. Id. at 365 .

The defendants also asserted that patronage dismissals increased accountability, because employees affiliated with the incumbent party were given an "incentive to perform well in order to insure their party's incumbency and thereby their jobs." Id. at 366. The plurality argued that less intrusive means, such as discharges for cause and merit systems that condition advancement on quality of performance, would achieve this goal. Id. Although the plurality rejected the accountability argument under the "least restrictive means" test, it should not be assumed that patronage dismissals increase accountability in any significant degree. Not all employees will perceive, much less appreciate, the relationship between their performance and their party's future, and those who do may believe the quality of their own performance will not be determinative.

${ }^{28} I d$. at 367.

${ }^{27}$ Id. at 367-68. The policy maker exception was modified in Branti v. Finkel, 445 U.S. 507,518 (1980). See text and notes at notes $47-49$ infra.

28427 U.S. at 368.

20 Id. at $382-87$.

so Id. at 369 .

s1 Id. at 372-73. Justice Brennan did suggest that the democratic process might function better without patronage because of its potential to skew the electoral process in favor of the incumbent party. Id. at 369.

${ }^{32}$ Id. at 353. 
broad terms. ${ }^{33}$ Justice Brennan spoke at several points of patronage practices in general rather than patronage dismissals in particular. ${ }^{34}$ Most noteworthy is his observation that patronage, "to the extent it compels or restrains belief and association, is inimical to the process which undergirds our system of government, and is 'at war with the deeper traditions of democracy embodied in the First Amendment." "ss

Justice Stewart, concurring in the judgment, was troubled by what he termed the plurality's "wide-ranging" discussion of the patronage system. ${ }^{36} \mathrm{He}$ emphasized that the Elrod holding should be confined strictly to the issue of patronage dismissals ${ }^{37}$ and justified the holding, so defined, by citing Perry $v$. Sindermann. ${ }^{38}$

\section{B. Branti v. Finkel}

Four years after Elrod, Branti v. Finkel ${ }^{39}$ presented the Supreme Court with another challenge to patronage dismissals. In that case, the Court reaffirmed the unconstitutionality of patronage dismissals, clarified the principles underlying its decision in Elrod, and narrowed Elrod's policy maker exception to the general proscription against patronage firings.

The controversy arose in early 1978 when the public defender of Rockland County, New York, a Democrat who had been appointed by the Democratic-dominated county legislature, began taking steps to dismiss six of the nine assistant public defenders.

ss The opinion noted other aspects of the patronage system, including hiring, the award of government benefits, and the allocation of government services. Id.

s4 See, e.g., id. at 355, 359, 369. Justice Powell in dissent read Justice Brennan's opinion as reaching patronage hiring as well as firing. Id. at 386. Justice Powell suggested that applicants for government jobs have a more compelling argument for relief than "complaining employees who apparently accepted patronage jobs knowingly and willingly, while fully familiar with the "tenure' practices" of which they complain. Id. at 380.

${ }^{35}$ Id. at 357 (quoting Illinois State Employees Council 34 v. Lewis, 473 F.2d 561, 576 (7th Cir. 1972) (Stevens, J.)), cert. denied, 410 U.S. 928 (1973).

36 427 U.S. at 374 (Stewart, J., concurring).

${ }^{37}$ This case does not require us to consider the broad contours of the so-called patronage system, with all its variations and permutations. In particular, it does not require us to consider the constitutional validity of a system that confines the hiring of some governmental employees to those of a particular political party, and I would intiId. mate no views whatever on that question.

38 Id. at 375. See text and note at note 20 supra. The concurring opinion also recognized an exemption for policy making and confidential positions from the ban against patronage dismissals. 427 U.S. at 375.

so 445 U.S. 507 (1980). 
With one possible exception, the nine assistants chosen for the new staff were all party loyalists selected by the Democratic organization. Two of the assistants targeted for dismissal, both Republicans, filed suit to enjoin their terminations, alleging that they were being punished for their political beliefs. ${ }^{40}$ Relying on Elrod, the district court enjoined the dismissals, ruling that the public defender must allow the plaintiffs to continue in their jobs and that he must not merely pay their salaries while distributing their duties to others. ${ }^{41}$ The Second Circuit affirmed without opinion. ${ }^{42}$

The public defender argued before the Supreme Court that Elrod applied only to employees who were dismissed after refusing to work for the incumbent party ${ }^{43}$ and that in any event, assistant public defenders were policy-making, confidential employees who were therefore within Elrod's exception." In an opinion written by Justice Stevens, ${ }^{45}$ the Court rejected the formalistic argument that Elrod permitted dismissal on the basis of political affiliation as long as the employee was never asked to affiliate with the party in power, declaring that such an interpretation would "emasculate" the principles set forth in that opinion. ${ }^{18}$

The Court expressed dissatisfaction, however, with Elrod's

10 At the suggestion of the district attorney, a Democrat, one of the plaintiffs had changed his party registration in 1977 in a futile attempt to obtain reappointment by the new Democratic public defender. The district court subsequently found that despite the plaintiff's change of party registration, the defendants had regarded him as a Republican at all times. Finkel v. Branti, 457 F. Supp. 1284, 1285 n.2 (S.D.N.Y. 1978), aff'd mem., 598 F.2d 609 (2d Cir. 1979), aff'd, 445 U.S. 507 (1980).

4 Id. at $1285-86$ n.4.

42 Branti v. Finkel, 598 F.2d 609 (2d Cir. 1979), aff'd, 445 U.S. 507 (1980).

43445 U.S. at 512. In effect, the defendants sought to confine the Elrod doctrine to situations where dismissal is threatened to influence incumbents' choice of partisan affiliation, as opposed to situations where dismissal is outright to make room for the party faithful.

4Id.

4s Chief Justice Burger and Justices Marshall, Brennan, White, and Blackmun joined that opinion. Justices Powell, Stewart, and Rehnquist dissented.

48 U.S. at 513. With respect to the first rationale offered by the Elrod plurality-the tendency of a patronage system to coerce employees into compromising their true beliefs-the Court reasoned that mere knowledge that one would be required to affliate with, or be sponsored by, the controlling party to keep his job would have coercive effects on belief. To illustrate, the Court pointed to the change of party registration by one of the plaintiffs in an attempt to retain his job. Id. at $516 \mathrm{n} .11$. With respect to the plurality's second argument - that patronage imposes an unconstitutional condition on the receipt of a public benefit-the Court in Branti asserted that "petitioner's interpretation would require [it] to repudiate entirely the conclusion of both Mr. Justice Brennan and Mr. Justice Stewart that the First Amendment prohibits the dismissal of a public employee solely because of his private political beliefs." Id. at 516-17. 
formulation of the policy maker exception. ${ }^{47}$ It articulated a new test: "the ultimate inquiry is not whether the label 'policymaker' or 'confidential' fits a particular position; rather, the question is whether the hiring authority can demonstrate that party affiliation is an appropriate requirement for the effective performance of the public office involved."48 Applying this standard, the Court concluded that the continued employment of an assistant public defender, whose duties consisted primarily of representing indigents accused of crimes, could not be conditioned on his political affiliation. ${ }^{48}$

Once again the Court rejected the argument that patronage is justified by the need to strengthen political parties so as to protect the democratic process; ${ }^{50}$ once again Justice Powell dissented. ${ }^{51}$ Where Elrod had reasoned that parties would not suffer materially from the interdiction of patronage dismissals, ${ }^{52}$ Branti argued that the benefits of patronage accrue only to the party in power and that the interest asserted was therefore strictly partisan, not

47 The Court noted that some positions, such as precinct watchers, appropriately could be considered political although of neither a policy making nor a confidential nature. At the same time, political affiliation is not relevant to every policy making or confidential position. Justice Stevens suggested the position of head football coach at a state university as an example. Id. at 518. These illustrations provide little guidance to lower courts charged with implementing the new standard.

Recognizing this uncertainty, the Seventh Circuit recently established its own test: a particular position may be filled on patronage grounds if "the position held by the individual authorizes, either directly or indirectly, meaningful imput into government decisionmaking on issues where there is room for principled disagreement on goals or their implementation." Nekolny v. Painter, 653 F.2d 1164, 1170 (7th Cir. 1981). This formulation should provide the courts as well as hiring authorities with more guidance than the tests of Elrod and Branti.

48445 U.S. at 508.

49 Id. at 519.

so $I d$. at 513 n.7.

51 Id. at 520. Justice Powell restated his position that the individual harm was outweighed by the governmental interests promoted by patronage, which included political participation, implementation of partisan policies, and preservation of effective cooperation between the legislative and executive branches. Id. at 524-31.

Justice Powell also argued that the Court's decision "may impair the right of local voters to structure their government." Id. at 532. He viewed Rockland County's system, in which the county legislature appointed the public defender, who named his own assistants, as one in which the voters gave the legislature their proxy to choose public officials. Justice Powell's argument is artificial, because there is only a tenuous connection between the election and the appointment of minor public officials. It is unlikely that citizens who go to the polls to elect representatives see themselves as choosing process servers, clerical workers, or assistant public defenders. That these officials are not chosen through the electoral process suggests that their selection is not meant to be based on partisan grounds.

${ }^{12} 427$ U.S. at $368-70$. 


\section{governmental.ss}

The cursory manner in which the Court advanced this argument has been criticized as insensitive to the realities of the political process. ${ }^{54}$ Its opinion also seems inconsistent with previous decisions that had acknowledged the importance to democracy of a strong party system. ${ }^{55}$ Using patronage to build strong parties may well be improper even apart from its adverse impact on public employees. ${ }^{58}$ The Court did not address this sharply disputed issue, however. Instead, it mistook the means, strong political parties, for the end, preservation of a healthy democratic system, and its reasoning ignored the argument that the means promoted are necessary to achieving the end.

\section{Patronage Employment Practices Short of Dismissal}

\section{Like Elrod, Branti's holding was limited to dismissals. ${ }^{52}$ Yet} the implications of these opinions reach further and may be reflected in the Court's statement in Branti that "it is difficult to formulate any justification for tying either the selection or reten-

ss 445 U.S. at 517-18 n.12. The Court reasoned that "[g]overnment funds, which are collected from taxpayers of all parties on a nonpolitical basis cannot be expended for the benefit of one political party simply because that party has control of the government." Id. The Elrod plurality had noted this concern, cautioning that "care must be taken not to confuse the interests of partisan organizations with governmental interests." 427 U.S. at 362.

s4 See, e.g., Loughney v. Hickey, 635 F.2d 1063, 1067-70 (3d Cir. 1980) (Aldisert, J., concurring).

ss See Buckley v. Valeo, 424 U.S. 1, 98, 101 (1976) (per curiam) (upholding in part the constitutionality of the Federal Election Campaign Act of 1971); Storer v. Brown, 415 U.S. 724,736 (1974) (upholding the constitutionality of a California law imposing restrictions on ballot access by independent candidates).

so Justice Brennan briefly addressed this concern in Elrod, noting that a party in power can use patronage to extort significant support-financial, electoral, and otherwise-at the expense of other parties, thereby tipping the electoral process in favor of the incumbent party and impeding democratic government. 427 U.S. at 356, 369-70. See also Shakman v. Democratic Organization of Cook County, 435 F.2d 267 (7th Cir. 1970), cert. denied, 402 U.S. 909 (1971), on remand, 481 F. Supp. 1315 (N.D. Ill. 1979). In that case, the plaintiffs, an independent candidate for delegate to the state constitutional convention and one of his supporters, were held to have stated a cause of action in charging that Chicago's patronage system skewed the electoral process, violating the candidate's interest in an equal chance of prevailing in the election and the supporter's interest in having as effective a voice in government as other voters. The court ruled that these interests are protected from such invidious official discrimination by the fourteenth amendment's equal protection clause. See generally Note, Political Patronage and the Independent Candidate: Shakman v. Democratic Organization of Cook County, 66 Nw. U.L. Rev. 390 (1971); 84 HaRv. L. Rev. 1547 (1971). Although Justice Stevens was a member of the Seventh Circuit when it upheld the complaint in Shakman, he did not mention that case in his Branti opinon.

87445 U.S. at 513 n.7. 
tion of an assistant public defender to his party affiliation."s8

Several federal courts considering the issue of political discrimination in public employment have assumed that the principles articulated in Elrod and Branti apply to personnel actions other than dismissals. ${ }^{59}$ Other courts, however, have been reluctant to give the patronage doctrine a broad construction. ${ }^{B 0}$ Thus the scope of patronage employment practices forbidden by the first amendment remains an open question.

\section{A. Constructive Discharges}

In response to civil service legislation prohibiting partisan dismissals, ${ }^{61}$ many federal agencies developed a variety of techniques for ridding themselves of incumbent jobholders without actually discharging them. For example, an incumbent might be reassigned to an unpleasant or professionally unproductive duty station ${ }^{62}$ or given onerous travel requirements, with the objective of forcing him either to resign or to disobey an order, thereby inviting dismissal. ${ }^{\text {B3 }}$ Such practices are known as constructive discharges. ${ }^{\text {s4 }}$

ss Id. at 520 n.14 (emphasis added). Justice Powell in dissent read this language as eliminating any constitutional distinction between the hiring and firing of public employees. Id. at 522 n.2.

${ }_{68}$ See Stegmaier v. Trammell, 597 F.2d 1027, 1031-32 n.4 (5th Cir. 1979) (demotion within Elrod's proscription but partisan motivation not proved); Aufiero v. Clarke, $489 \mathrm{~F}$. Supp. 650 (D. Mass. 1980) (demotion within Elrod's proscription, but position unprotected), aff'd on other grounds, 639 F.2d 49 (1st Cir. 1981); Miller v. Board of Educ., 450 F. Supp. 106 (S.D.W. Va. 1978) (transfers and demotions); DeLuca v. Sullivan, 450 F. Supp. 736 (D. Mass. 1977) (failure to promote); Morris v. City of Kokomo, 381 N.E.2d 510, 516-17 (Ind. Ct. App. 1978) (demotions). Cf. Guerra v. Roma Independent School Dist., 444 F. Supp. 812 (S.D. Tex. 1977) (teacher placed on probation); Tanner v. McCall, 441 F. Supp. 503, 512 (M.D. Fla. 1977) (harassment), modified on other grounds, 625 F.2d 1183 (5th Cir. 1980); Cullen v. New York State Civil Serv. Comm'n, 435 F. Supp. 546 (E.D.N.Y.) (failure to promote and demotion), appeal dismissed, 566 F.2d 846 (2d Cir. 1977); Vega Matta v. Alvarez de Choudens, 440 F. Supp. 246 (D.P.R. 1977) (transfer), aff'd mem., 577 F.2d 722 (1st Cir. 1978).

${ }^{\circ}$ See, e.g., Delong v. United States, 621 F.2d 618, 624 (4th Cir. 1980) (patronage transfers impermissible only if "tantamount to" dismissal); Ramey v. Harber, 589 F.2d 753, 757 (4th $\mathrm{Cir}$. 1978) (dictum suggesting that Elrod may be inapplicable to failures to reappoint for partisan reasons), cert. denied, 442 U.S. 910 (1979); Mulherin v. O'Brien, 588 F.2d 853, 857 (1st Cir. 1978) (dictum objecting to extension of Elrod as further interference with states' freedom to structure their governments; appellants failed to allege that they were penalized for their political affiliation).

or See 5 U.S.C. $\$ 3301$ (1976).

62 See R. Vaughn, The Spolled System 19 (1975).

63 For further documentation of such evasive bureaucratic techniques, see SuBcomm. ON Manpower and Civil Service of the House Comm. on Post Office and Civil Service, 94th Cong., 2d Sess., Final Report on Violations and Abuses of Merit Principles in Federal 
These bureaucratic techniques may be employed just as readily to circumvent the proscriptions of Elrod and Branti, serving only to reward a new administration's ingenuity in devising methods to rid itself of political undesirables and create vacancies to be filled by patronage.

In Delong $v$. United States, ${ }^{65}$ the Fourth Circuit recognized that proscription of such practices is a "necessary implication"Bs of the Elrod-Branti doctrine. The case involved the conflict that arose in 1977 when the new Secretary of Agriculture began replacing Republican state directors of the Farmers Home Loan Administration with Democratic appointees. ${ }^{67}$ Mahlon M. Delong, the director for Maine, had special statutory rights as a military veteran that prohibited his discharge without cause. ${ }^{68}$ The Secretary created a number of positions for "program assistants" to which incumbent Republican directors with the veterans' preference could be transferred if they refused to resign. Delong's new position car-

Employment 160-64, 804-11 (Comm. Print 1976).

64 The doctrine of constructive discharge was developed to prevent employers from circumventing section 8(a)(3) of the National Labor Relations Act, 29 U.S.C. \$158(a)(3) (1976) (forbidding discrimination on the basis of union membership), by deliberately making an employee's working conditions so intolerable that he would be forced to resign. See J.P. Stevens \& Co. v. NLRB, 461 F.2d 490, 494-95 (4th Cir. 1972). The doctrine also has been applied to cases arising under Title VII of the Civil Rights Act of 1964, 42 U.S.C. $\$ \S 2000$ e2000e-17 (1976 \& Supp. III 1979). See Jacobs v. Martin Sweets Co., 550 F.2d 364, 369-70 (6th Cir.), cert. denied, 431 U.S. 917 (1977); Young v. Southwestern Sav. \& Loan Ass'n, 509 F.2d 140, 143-44 (5th Cir. 1975).

With respect to both section 8(a)(3) and Title VII, discrimination in the conditions of employment is enough to establish a violation and justify an award of damages. A finding of constructive discharge is relevant only to the scope of the remedy and may entitle the plaintiff to reinstatement and/or back pay covering the period after resignation. See Muller v. United States Steel Corp., 509 F.2d 923, 930 (10th Cir.) ("Unless appellant was constructively discharged, he would not be entitled to damages in the form of back pay, interest and retirement from the date of leaving [defendant's] employ."), cert. denied, 423 U.S. 825 (1975); NLRB v. Tennessee Packers, Inc., 339 F.2d 203, 204-05 (6th Cir. 1964) (reinstatement order enforced after National Labor Relations Board's finding of constructive discharge upheld).

Two elements must be proved to support a finding of constructive discharge in violation of section 8(a)(3). "First, the burdens imposed upon the employee must cause, and be intended to cause, a change in his working conditions so difficult or unpleasant as to force him to resign. Second, it must be shown that those burdens were imposed because of the employee's union activities." Crystal Princeton Refining Co., 222 N.L.R.B. 1068, 1069, 91 L.R.R.M. 1302, 1303 (1976). See also J.P. Stevens \& Co. v. NLRB, 461 F.2d 490, 494 (4th Cir. 1972); Montgomery Ward \& Co. v. NLRB, 377 F.2d 452, 459 (6th Cir. 1967).

os 621 F.2d 618 (4th Cir. 1980).

ss Id. at 624.

67 State directors were exempted from the competitive civil service. Id. at 621 .

os See 5 U.S.C. \$§ 7511-7513 (Supp. III 1979). 
ried the same pay, civil service grade, and fringe benefits as the old, but his responsibilities were greatly diminished. ${ }^{\text {98 }}$

Delong filed suit, arguing that Elrod prohibited the Secretary's actions. The district court dismissed the complaint, holding that the position of state director fell within Elrod's policy maker exception. ${ }^{70}$ While the decision was on appeal before the Fourth Circuit, the Supreme Court in Branti narrowed that exception; ${ }^{71}$ the Fourth Circuit remanded the case to the district court for reconsideration in light of the Branti test. ${ }^{22}$ Although the case involved a reassignment rather than a discharge, the Fourth Circuit in remanding rejected the government's contention that as a matter of law, transfers and reassignments were not injuries of a constitutional magnitude. ${ }^{73}$ Instead, it ruled that the Elrod principle includes "patronage practices" other than dismissal "that can be determined to be the substantial equivalent of dismissal."74 The court explained that "the issue thus becomes whether the specific reassignment or transfer . . . impose[s] upon the employee such a Hobson's choice between resignation and surrender of protected rights as to be tantamount to outright dismissal."75

Without mentioning the term explicitly, it is clear that Delong forbade the practice of constructive discharge. ${ }^{78}$ Although the court stopped short of requiring a showing of intent to force the

69 As the state director, the plaintiff had final authority over $\$ 130$ million in loans and responsibility for program planning and implementation. On reassignment to Washington, he was given no secretary or staff, asked to write insignificant reports, and required to travel extensively on short notice to distant locations. 621 F.2d at 621 .

70 Id.

${ }^{71}$ See text and notes at notes 47-49 supra.

72621 F.2d at 621.

${ }^{73}$ Id. at 618, 622-23; cf. Nekolny v. Painter, 653 F.2d 1164, 1166 (7th Cir. 1981) (resignation of one of three plaintiffs precipitated by reduction in pay and responsibilities; without using the term "constructive discharge," court repeatedly referred to plaintiff"s "termination," finding it actionable under Elrod). Contra, Delong v. United States, 621 F.2d at 626 (Dumbauld, J., concurring) (no injury to plaintiff, "however unhappy he may be in leaving the lobster-pots of Maine for the hot summers of the nation's capital"); Johnson v. Bergland, 586 F.2d 993, 996 (4th Cir. 1978) (Hall, J., dissenting) (expressing doubt that "a job transfer to Mississippi is an injury of constitutional magnitude" and commenting that such a proposition "might startle the citizens of that state").

74621 F.2d at 623-24.

${ }^{76}$ Id. at 624 . On remand, Delong met his burden of showing that his transfer was "tantamount to" a dismissal. Delong v. United States, No. 78-294-A (E.D. Va. Sept. 18, 1980).

${ }^{38}$ Unlike cases under Title VII and the NLRA, see note 64 supra, the relevance of a finding of constructive discharge in a patronage case is not limited to the scope of the remedy but, under Delong, is necessary to establish a constitutional violation in the first place. 621 F.2d at 623 . 
employee to resign, the factual inquiry posed by Delong seems designed to be especially sensitive to the constructive discharge problem. ${ }^{77}$

\section{B. Nondischarges}

It is unclear whether the principles of Elrod and Branti extend to patronage actions of less ultimate severity than actual or constructive discharge. Such actions include demotions, failures to promote, transfers or reassignments, and decisions concerning pay, benefits, or awards. ${ }^{78}$

Branti may have hinted that such actions are forbidden when it endorsed the district court's ruling that plaintiffs be "retain[ed] ... in their prior positions, with full privileges as employees,"70 and not merely paid their salaries. In addition, several federal and state courts either have held or have indicated in dictum that they would hold one or more of the above-mentioned actions unconstitutional if taken because of an employee's political beliefs or associations. ${ }^{80}$ Morris $v$. City of Kokomo ${ }^{81}$ is typical. The case involved the demotions of an assistant fire chief and a district fire chief for partisan reasons, with reductions in pay and work responsibilities. Conceding that the tangible consequences of a discharge are greater than those of a "simple demotion,"82 the Indiana Court of Appeals reasoned that requiring employees to support a particu-

77 In determining whether transfers are "tantamount to" dismissal, the court suggested consideration of the "subjective expectations and reliance on the officeholder's part in relation to the particular position held, that were actually or constructively known to the official making or threatening the transfer or reassignment . . ." 621 F.2d at 624. This concern with intent to discourage protected activity is misplaced; in other contexts proof that a personnel decision discouraged the aggrieved employee's protected activities satisfies the intent requirement. See, e.g., Radio Officers' Union v. NLRB, 347 U.S. 17, $44-45$ (1954) (rule that "specific proof of intent is unnecessary where employer conduct inherently encourages or discourages union membership is but an application of the common-law rule that a man is held to intend the foreseeable consequences of his conduct"). Moreover, invocation of the unconstitutional conditions doctrine does not depend on evidence of a specific intent to discourage protected activity; all that must be shown is that the government's action is based on some consideration that inhibits the employee's exercise of protected activity. See note 21 supra.

78 These actions may be motivated by a variety of political objectives: punishment of the employee for not supporting the victorious party, pressuring the employee into supporting the party in power, or, where promotions and perquisites are limited, rewarding the party faithful at the expense of nonconformists.

79445 U.S. at 509 n.3 (emphasis added).

so See cases cited supra note 59.

s1 381 N.E.2d 510 (Ind. Ct. App. 1978).

${ }^{82}$ Id. at 518. 
lar candidate to preserve their current rank coerced them in the same manner as victims of patronage dismissals were coerced..$^{83} \mathrm{Al}$ though the particular demotions involved in Morris were severe, ${ }^{84}$ the court spoke in terms of adverse job actions in general. ${ }^{85}$

Other courts have construed the reach of Elrod and Branti much more narrowly. Although rejecting the contention that Elrod should be limited to actual dismissals, the Fourth Circuit in Delong refused to forbid all patronage transfers. ${ }^{86}$ Instead, the court held that even where the government fails to satisfy the Branti burden of establishing the need to fill a position on patronage grounds, incumbents may be reassigned to advance patronage aims unless it can be shown that their exclusion from a position would be "the substantial equivalent" of a dismissal from government service. ${ }^{87}$ Basing its decision on a reluctance to give public employees more protection than that accorded their private counterparts ${ }^{88}$ the court held that the first amendment is violated only when the challenged action "imposed so unfair a choice between continued employment and the exercise of protected beliefs and associations as to be tantamount to the choice imposed by threatened dismissal." "39

The conflict can be resolved only by analyzing patronage employment practices under the principles enunciated in Elrod and clarified by Branti. The first reason for proscribing patronage dismissals, originally advanced only by the plurality in Elrod but later embraced by the Branti majority, is their potentially coercive impact on political belief and association. ${ }^{90}$ First amendment jurisprudence emphasizes the effects of actions rather than the actions themselves," and inquiry properly is focused simply on "whether the adverse action taken by the defendants is likely to chill the exercise of constitutionally protected [rights]." ${ }^{\text {"92 }}$ All that need be

ss $I d$.

84 The plaintiffs were "demoted to the rank of private." Id. at 512.

8s Id. at 518.

so 621 F.2d at 623-24.

${ }^{87}$ Id. at 624 .

s8 $I d$.

sa Id.

9o See text and notes at notes $15-18,46$ supra.

91 See Aebisher v. Ryan, 622 F.2d 651, 653 (2d Cir. 1980); McGill v. Board of Educ., 602 F.2d 774, 780 (7th Cir. 1979). See also Pickering v. Board of Educ., 391 U.S. 563, 574 (1968) (discussing coercive impact of criminal sanctions on first amendment activity).

${ }_{82}$ McGill v. Board of Educ., 602 F.2d 774, 780 (7th Cir. 1979) (citing Pickering v. Board of Educ., 391 U.S. 563, 574 (1968)). 
shown to state a cause of action is that the "constrictive impact . . . arise[s] from the present or future exercise, or threatened exercise, of coercive power." ${ }^{\text {93 }}$ It is artificial to evaluate the particular action involved without inquiring into its potential chilling effect.94

The adverse effects that patronage personnel actions may exert on political association are substantial. The courts long have recognized that sanctions affecting an individual's career have a particularly devastating effect on the exercise of first amendment rights. Employment discrimination has been described as

one of the most deplorable forms of discrimination known to our society, for it deals not with just an individual's sharing in the "outer benefits" of being an American citizen, but rather the ability to provide decently for one's family in a job or profession for which he qualifies and chooses. ${ }^{28}$

Employees naturally are inclined to "avoid any ties which might displease those who control [their] professional destin[ies]." ${ }^{\text {"日e }}$ Congress has recognized in a related context that the threat of adverse personnel actions far short of dismissal may deter valuable conduct

os Reporters Comm. for Freedom of the Press v. AT\&T, 593 F.2d 1030, 1052 (D.C. Cir. 1978) (footnote omitted), cert. denied, 440 U.S. 949 (1979). See also Bigelow v. Virginia, 421 U.S. 809, 816-17 (1975); Laird v. Tatum, 408 U.S. 1, 13-14 (1972).

* Where employment sanctions allegedly punish protected speech, as opposed to the associational rights implicated in patronage employment cases, federal courts have recognized that this chilling effect can be accomplished through demotions, transfers, and other actions short of dismissal. See, e.g., McGill v. Board of Educ., 602 F.2d 774, 779-80 (7th Cir. 1979) (teacher's transfer in retaliation for collective bargaining activities); Simpson v. Weeks, 570 F.2d 240, 241-42 (8th Cir. 1978) (police officer's transfer and poor performance ratings due to his disclosure to the public of official misconduct), cert. denied, 443 U.S. 911 (1979); Rosado v. Santiago, 562 F.2d 114, 117-18 (1st Cir. 1977) (administrator's transfer prompted by his criticism of agency inefficiency). But see Stone v. Board of Regents of the University System, 620 F.2d 526, 529 n.7 (5th Cir. 1980) (refusing to decide whether denials of pay raises, promotions, and other employment decisions are actionable).

It would be unwarranted to impose one standard of injury where protected speech is chilled and another, stricter standard where rights of association are implicated. See generally Finley v. Hampton, 473 F.2d 180, 184 (D.C. Cir. 1972). The standard should be uniform, for freedom of association is "a right which, like free speech, lies at the foundation of a free society." Shelton v. Tucker, 364 U.S. 479, 486 (1960). See also Elrod v. Burns, 427 U.S. 347, 356-57 (1976).

As with the political association cases, the speech cases permit an inquiry into whether the employee's constitutional interests are outweighed by the interest of the state as an employer in promoting the efficiency of the public services it performs. See Pickering v. Board of Educ., 391 U.S. 563, 568 (1968). This factor, however, goes to the justifications for a given action, rather than to the initial decision whether an action is suspect.

5 Culpepper v. Reynolds Metals Co., 421 F.2d 888, 891 (5th Cir. 1970) (Title VII case).

Shelton v. Tucker, 364 U.S. 479, 486 (1960). 


\section{by public employees..$^{97}$}

The second reason articulated in Elrod and Branti in opposition to patronage dismissals-that the practice imposes an unconstitutional condition on the receipt of a public benefit-applies equally to sanctions short of dismissal. ${ }^{98}$ The enjoyment of a benefit granted by the government, be it a tax exemption, ${ }^{89}$ unemployment compensation, ${ }^{100}$ a home in a public housing project, ${ }^{101}$ or a term of employment, ${ }^{102}$ cannot be made to depend on the grantee's submission to unjustifiable conditions that infringe his first amendment rights. Any adverse action against an employee based on his political affiliation penalizes protected activity, and any such penalty should be constitutionally suspect. ${ }^{103}$

97 The Civil Service Reform Act of 1978, 5 U.S.C. $\S \S 1101-8913$ (Supp. III 1979), includes provisions designed to protect "whistleblowers"-government employees who disclose illegality, waste, and corruption-from retaliation and harassment. Id. § 2301(b)(9). Congress intended these provisions to encourage employees to disclose agency wrongdoing and abuse by eliminating the prospect of prejudice to their careers. S. REP. No. 969, 95th Cong., 2d Sess. 22, reprinted in 1978 U.S. CodE CoNG. \& AD. News 2723, 2744. To facilitate this goal, the Act details a list of prohibited personnel practices, 5 U.S.C. § 2302(b) (Supp. III 1979), covering the following personnel actions:

(i) an appointment;

(ii) a promotion;

(iii) ... disciplinary or corrective action;

(iv) a detail, transfer, or reassignment;

(v) a reinstatement;

(vi) a restoration;

(vii) a reemployment;

(viii) a performance evaluation ....;

(ix) a decision concerning pay, benefits, or awards, concerning education or training if the education or training may reasonably be expected to lead to an appointment, promotion, performance evaluation, or other action described in this subparagraph; and

$(x)$ any other significant change in duties or responsibilities which is inconsistent with

the employee's salary or grade level . . . .

Id. $\$ 2302(a)(2)(A)$. This enumeration indicates that the effects of these actions are regarded by Congress as having strong inhibiting effects on protected employee activities. Arguably, some of these actions, such as adverse performance evaluations, would not by themselves satisfy the Supreme Court's standing requirements. See text and notes at notes 110-111 infra. But see Yoggerst v. Stewart, 623 F.2d 35, 41 (7th Cir. 1980) (official reprimand may be actionable).

${ }^{98}$ See text and notes at notes $19-22,46$ supra. Branti implied that the unconstitutional conditions doctrine, presumably because of its invocation in both the plurality and concurring opinions in Elrod, was the theory on which it would rely primarily in evaluating challenges to patronage in the future. 445 U.S. at 516-17.

${ }^{28}$ Speiser v. Randall, 357 U.S. 513, 518 (1958).

100 Sherbert v. Verner, 374 U.S. 398, 404 (1963).

101 Thorpe v. Housing Authority, 386 U.S. 670, $678-79$ (1967) (Douglas, J., concurring).

103 See text and notes at notes 19-21 supra.

${ }^{103}$ Both the plurality in Elrod and the Court in Branti noted that the invocation of the unconstitutional conditions doctrine did not depend on the severity of the coercive effect of 
It remains to be considered whether the benefits to the government of a particular patronage practice justify the infringement of first amendment rights. Even when measured against the less intrusive sanction of demotion or transfer, the justifications offered in support of patronage fall far short of the mark. For example, it has been argued that patronage-based personnel decisions lead to greater government efficiency. ${ }^{104}$ Yet the government's interest in efficiency actually may be promoted rather than impeded by the elimination of partisan considerations from personnel decisions. To make the success of public employees' careers dependent on their political affiliation would result in disharmony and poor morale, for political favors rather than diligent performance would be rewarded. Both Congress and the Court have recognized the "danger ... that political rather than official effort may earn advancement," 105 leading to the "conviction that an actively partisan governmental personnel threatens good administration."106

In urging that Elrod and Branti not be extended to practices other than dismissal, critics of those decisions have argued that the civil service system insulates public employees from discipline and that the patronage system leads to greater accountability. ${ }^{107}$ It also

patronage on political association. Branti v. Finkel, 445 U.S. 507, 516-17 (1980); Elrod v. Burns, 427 U.S. 347, 358 n.11 (1976).

The Court's decisions applying the unconstitutional conditions doctrine have focused on the deterrent effect the condition exerts on the exercise of constitutional rights rather than on the condition itself. See, e.g., Pickering v. Board of Educ., 391 U.S. 563, 574 (1968) ("While criminal sanctions and damage awards have a somewhat different impact on the exercise of the right to freedom of speech from dismissal from employment, it is apparent that the threat of dismissal from public employment is nonetheless a potent means of inhibiting speech."); United States v. Robel, 389 U.S. 258, 265 (1967) (statute making it unlawful for members of particular organizations to be employed in defense facilities imposed an "inhibiting effect on the exercise of First Amendment rights"); Sherbert v. Verner, 374 U.S. 398,404 (1963) (denial of unemployment compensation based on plaintiff's refusal, in accordance with her religion, to work on Saturdays created "pressure . . . to forego that practice"); Speiser v. Randall, 357 U.S. 513, 518 (1958) (deterrent effect of discriminatory denial of tax exemption for engaging in speech "is the same as if the State were to fine [plaintiffs] for ... speech").

204 Branti v. Finkel, 445 U.S. 507, 529-31 (1980) (Powell, J., dissenting).

105 United Public Workers v. Mitchell, 330 U.S. 75, 98 (1947) (construing the Hatch Act).

${ }^{108}$ Id. at 97-98. See also United States Civil Serv. Comm'n v. National Ass'n of Letter Carriers, 413 U.S. 548, 564 (1973); Ex parte Curtis, 106 U.S. 371, 373-74 (1882). Of course, Elrod and Branti allow for partisan employment if the government can demonstrate that party affiliation is an appropriate requirement for a particular position. See text and notes at notes $27,47-49$ supra.

${ }^{107}$ See Branti v. Finkel, 445 U.S. 507, 531 (1980) (Powell, J., dissenting); Elrod v. Burns, 427 U.S. 347, 385 (1976) (Powell, J., dissenting); Loughney v. Hickey, 635 F.2d 1063, 
might be argued that extension of Elrod to all personnel decisions would invite a flood of litigation by paranoid or vengeful employees, leading to a bureaucratic paralysis in which officials were afraid to discipline or dismiss employees for fear of being sued for their "partisan" motivations.

There is no good reason for these concerns to outweigh the first amendment values at stake. First, energetic and responsive management of the bureaucracy can be maintained by permitting the selection of upper-level officials on partisan grounds. ${ }^{108}$ Second, forbidding patronage employment practices is not the equivalent of imposing a civil service structure ${ }^{109}$ for such a rule does not require time-consuming grievance and investigatory procedures, notice, hearing, or explanation. Moreover, first amendment jurisprudence requires that plaintiffs assert "claim[s] of specific present objective harm, or ... threat[s] of specific future harm"110 to gain standing to challenge the government's employment actions. ${ }^{111}$ In addition, because employees bear the substantial burden of proving that improper partisan considerations played a part in their superiors' decisions, ${ }^{112}$ frivolous litigation should not prove a major problem. Finally, the government itself is the single greatest determinant of the volume of patronage litigation. As Justice Stevens observed during his tenure on the Seventh Circuit, "[t]he price which a government must pay to protect the constitutional liber-

1065-66 (3d Cir. 1980) (Aldisert, J., concurring); Flintner, Bring Back the Spoils System to Make Government Work, B. GLOBE, Oct. 15, 1980, at 17, col. 1; Peters, A Kind Word for the Spoils- System, WASH. MonTHLY, Sept. 1976, at 29.

108 If the Court continues not to provide meaningful guidance as to when political affiliation is a permissible selection criterion, see note 47 supra, the government's ability to select and attract upper-level officials could be frustrated. If hiring officials have no guidelines, they may be timid where they should fill positions with partisan considerations in mind, thereby threatening effective policy implementation. See, e.g., Branti v. Finkel, 445 U.S. 507, 524 (1980) (Powell, J., dissenting).

109 See Illinois State Employees Council 34 v. Lewis, 473 F.2d 561, 567 (7th Cir. 1972), cert. denied, 410 U.S. 928,943 (1973).

110 Laird v. Tatum, 408 U.S. 1, 14 (1972).

11 Cf. Bigelow v. Virginia, 421 U.S. 809, 816-17 (1975) (upholding standing of newspaper editor to challenge statute making it illegal, by the sale or circulation of any publication, to encourage the procuring of an abortion); Finley v. Hampton, 473 F.2d 180, 182, 184 (D.C. Cir. 1972) (no "cognizable legal injury" shown in employee's first amendment challenge to the inclusion in his file of a memo noting his association with homosexuals). The plaintiff must demonstrate that the chilling effect "upon the exercise of constitutional rights arises in the context of an extant or imminently threatened government sanction." Id. at 185. See also Schoen, Politics, Patronage, and the Constitution, 3 IND. Legal F. 35, 59 n.88 (1969). 112 See, e.g., Mount Healthy Bd. of Educ. v. Doyle, 429 U.S. 274, 287 (1977); Nekolny v. Painter, 653 F.2d 1164, 1168 (7th Cir. 1981). 
ties of its employees . . . will loom large only if it is assumed that political considerations will motivate a large number of employment decisions."11s If this assumption is unfounded, the amount of litigation generated by giving full effect to the principles in Elrod and Branti should not seriously hamper effective administration.

The court in Delong also argued that forbidding all patronage employment actions would grant to public employees an unwarranted advantage over workers in the private sector. ${ }^{114}$ This objection is misplaced, because the first and fourteenth amendments do not apply to private behavior. Actions by the government, however, are subject to these constraints, ${ }^{113}$ and the Supreme Court has admonished that "governments, even in the exercise of their internal operations, do not constitutionally have the complete freedom of action enjoyed by a private employer."116

The Fourth Circuit's requirement in Delong that the plaintiff prove that the challenged action was "tantamount to the choice imposed by threatened dismissal"117 is mischievous for two additional reasons. First, its constructive discharge standard is inherently subjective, inviting misinterpretation, abuse, and inconsistent results. ${ }^{118}$ Second, such a standard needlessly burdens the vindica-

113 Illinois State Employees Council 34 v. Lewis, 473 F.2d 561, 575 (7th Cir. 1972), cert. denied, 410 U.S. 928 (1973).

114 "The exigencies of reassignment and transfer normally incident to comparable levels of executive employment in the private sector of business and industry should generally be assumed normal incidents of government employment, without regard to the specific motivation behind a challenged transfer or reassignment." 621 F.2d at 624 . It is doubtful, however, that the public employee is being afforded any real advantage over his private counterpart, because few employment decisions in the private sector are based on political affiliation. See, e.g., Miller v. School Dist. No. 167, 495 F.2d 658, 665 n.29 (7th Cir. 1974).

${ }^{115}$ Although courts generally are reluctant to review personnel decisions made by public agencies, there is an explicit exception to this principle when a decision is alleged to have infringed on an employee's constitutional rights. See Bishop v. Wood, 426 U.S. 341, 350 (1976); DiPiro v. Taft, 584 F.2d 1, 3 (1st Cir. 1978), cert. denied, 440 U.S. 914 (1979); Doe v. Hampton, 566 F.2d 265, 271-72 (D.C. Cir. 1977); Megill v. Board of Regents, 541 F.2d 1073, 1077 (5th Cir. 1976). The government, however, may have a compelling interest in a particular practice or regulation that justifies some interference with an employee's exercise of his first amendment freedoms. See, e.g., United States Civil Serv. Comm'n v. National Ass'n of Letter Carriers, 413 U.S. 548, 564 (1973); United Public Workers v. Mitchell, 330 U.S. 75, 95-96 (1947).

${ }^{116}$ Cafeteria \& Restaurant Workers Local 473 v. McElroy, 367 U.S. 886, 898 (1961). See Abood v. Detroit Bd. of Educ., 431 U.S. 209, 226 n.23 (1977) (recognizing distinction between public and private employers).

${ }_{112}^{112} 621$ F.2d at 624. See text and notes at notes 86-89 supra.

118 The test outlined in Delong instructs that

in gauging the impact of a challenged patronage transfer or reassignment, it would be appropriate to take into account any special circumstances, including subjective expec- 
tion of constitutional rights. A plaintiff in a patronage case will be required to prove that his political affiliation was a motivating factor in the employment decision; ${ }^{119}$ the government can then attempt to establish the need to take the challenged action on the basis of partisan affiliation. If the government fails to demonstrate this need, it makes little sense to add another hurdle to what is already likely to be a protracted case by requiring the plaintiff to prove the elements of a constructive discharge. ${ }^{120}$

\section{Patronage Hiring}

Although the Court in Branti ruled that the government could not create patronage vacancies by discharging public employees affiliated with the party out of power, it expressly refused to consider the constitutionality of patronage appointments to positions made available through normal attrition or the creation of new jobs. ${ }^{121}$ Several lower courts either have held ${ }^{122}$ or have indicated in dictum ${ }^{123}$ that patronage hiring is unconstitutional; no decisions

tations and reliance on the officeholder's part in relation to the particular position held ... and that might reasonably be thought to increase the difficulty of the choice imposed upon the employee. For the same reason, any prior employment history of the officeholder that might bear upon the actual severity of impact of the challenged reassignment or transfer would be relevant to the inquiry. The ultimate issue .... is whether, all things considered, the challenged reassignment and transfer can reasonably be thought to have imposed so unfair a choice between continued employment and the exercise of protected beliefs and associations as to be tantamount to the choice imposed by threatened dismissal.

621 F.2d at 624.

119 See, e.g., Mount Healthy Bd. of Educ. v. Doyle, 429 U.S. 274, 287 (1977); Nekolny v. Painter, 653 F.2d 1164, 1168 (7th Cir. 1981). The state will prevail if it can convince the trier of fact that the same decision would have been made without regard to political affiliation. For a discussion of the burdens imposed by Mount Healthy on plaintiffs contesting patronage employment actions, see Columbia Comment, supra note 7, at 478-80.

120 The final interest asserted in patronage-preservation of the democratic process-even if still considered valid, see text and notes at notes 50-56 supra, would not be helpful in defending against challenges to personnel actions short of dismissal. That interest (specifically, the need to induce contributions of time and money to political campaigns) is dependent on the coercive effect of the patronage practice at issue. Yet that coercive effect is the very reason patronage is presumptively hostile to the Constitution. Thus it would be contradictory to argue that patronage actions short of dismissal do not have a significant coercive effect while simultaneously asserting the need to coerce partisan support.

121445 U.S. at 513 n.7.

122 See Cullen v. New York State Civil Serv. Comm'n, 435 F. Supp. 546, 551-52 (E.D.N.Y.) (denying dismissal of claim where plaintiffs alleged that hiring for government positions was conditional on making political contributions), appeal dismissed, 566 F.2d 846 (2d Cir. 1977).

${ }^{123}$ See Rosenthal v. Rizzo, 555 F.2d 390, 392 (3d Cir.), cert. denied, 434 U.S. 892 (1977); Aufiero v. Clarke, 489 F. Supp. 650, 653-54 (D. Mass. 1980), aff'd, 639 F.2d 49 (1st 
since Elrod have argued to the contrary. ${ }^{\mathbf{1 2 4}}$

Individuals who are required to affiliate with or work for a certain political party to obtain consideration for government employment are coerced in the same manner as those required to do so to retain their positions. In both cases benefits are withheld because of political affiliation. It might be argued that patronage hirings are less burdensome than patronage firings because the psychological and financial effects on individuals denied access to a relatively small sector of the job market are less serious than those on employees who have been stripped of their positions. ${ }^{125}$ Nevertheless, the incentive of employment is a powerful one, and the inducement to suppress one's political beliefs operates almost as forcefully on the person who seeks a position as it does on one who struggles to retain one. ${ }^{126}$

It also has been suggested that abolishing patronage hiring would have more serious consequences for the party system than the ban on patronage firings. ${ }^{127}$ Although the argument that patronage serves the democratic process appears to have been put to rest in $B r a n t i,{ }^{128}$ it has been argued that by forbidding patronage firings, the Court has increased the parties' dependence on patronage hiring to provide incentives necessary to attract donations of time and money. ${ }^{129}$

This argument is unconvincing. First, it is anomalous to suggest that guaranteeing the constitutional rights of one group (present employees) necessitates the withdrawal of those rights from another (prospective employees). Moreover, it is doubtful that the future of the party system depends on the retention of any type of patronage employment practice. Although patronage has been the linchpin of many local party organizations, ${ }^{130}$ many other state and

Cir. 1981); McKenna v. Fargo, 451 F. Supp. 1355, 1377 (D.N.J. 1978), aff'd mem., 601 F.2d 575 (3d Cir. 1979).

124 In Mazus v. Department of Transp., 629 F.2d 870 (3d Cir. 1980), cert. denied, 449 U.S. 112 (1981), the Third Circuit retreated from its dictum in Rosenthal v. Rizzo, 555 F.2d 390, 392 (3d Cir. 1977), that patronage hirings are unconstitutional. Finding no evidence that political affiliation was considered in evaluating the plaintiff's application for employment, however, the court found it unnecessary to reach that question. 629 F.2d at 873.

${ }^{125}$ See The Supreme Court, 1975 Term, 90 Hakv. L. REv. 56, 195 (1976); Columbia Comment, supra note 7, at 475-76.

${ }^{126}$ See generally Elrod v. Burns, 427 U.S. 347, 355 (1976).

127 Columbia Comment, supra note 7, at 475-76.

128 See text and notes at notes 51-56 supra.

129 See generally Columbia Comment, supra note 7, at 475-76.

${ }^{130}$ See generally L. O'Connor, Clout-Mayor Daley and His City (1975); M. Rakove, Don't Make No Waves-Don't Back No Losers (1975); M. Royko, Boss (1971). 
local parties have thrived without the benefit of a patronage system. ${ }^{131}$ Studies by political scientists suggest that job patronage today can explain only a small amount of party activity ${ }^{132}$ and that patronage hiring as an incentive for building party organizations and enforcing party discipline leaves much to be desired. ${ }^{133}$

\section{ConcLusion}

Failure to apply the principles of Elrod and Branti to patronage employment practices other than discharge sanctions the creation of two classes of public employees-those affiliated with the party in power, and those who are not. Employees in the latter group either must submit to the pressure to change their political affiliations or must suffer discriminatory treatment. Except where a position allows for "meaningful input"134 into the policy-making process, such a choice is contrary to the first amendment and must be forbidden. ${ }^{135}$

Roy E. Hoffinger

$13 x$ See Sorauf, Patronage and Party, 3 Mrdw. J. PoL. ScI. 115, 118-20 (1959).

192 See R. Blank, Political Parties 133 (1980); Sorauf, The Silent Revolution in Patronage, 20 PUB. AD. REv. 28, 29-30 (1960). A variety of factors cause people to become involved in party politics. Many party workers are motivated by ideological considerations; many participate because the contacts made in and publicity resulting from party work further their businesses. According to one authority, "the majority of persons who are active members of local party organizations seek neither material benefits nor the achievement of large ends, but merely find politics-or at least coming together in groups to work at politics-intrinsically enjoyable." J. Wilson, Political Organizations 110 (1973). See J. James, American Political Parties in Transition 87 (1974); J. Wilson, supra, at 133-35.

133 See Johnston, Patrons and Clients, Jobs and Machines: A Case Study of the Uses of Patronage, 73 AM. PoL. Scr. REv. 385, 397 (1979) (suggesting that the correlation between patronage hiring and high levels of active party support is weak). The use of patronage as a disciplinary weapon in intraparty struggles threatens the party strength that Justice Powell maintained is necessary for ensuring effective governance. Branti v. Finkel, 445 U.S. 507, 529 (1980) (Powell, J., dissenting). See W. Goodman, The Party System in America 37 (1980).

134 Nekolny v. Painter, 653 F.2d 1164, 1170 (7th Cir. 1981).

195 A variety of responses are available to remedy employment practices infringing on first amendment rights. Plaintiffs dismissed from their positions are entitled to injunctive relief in the form of reinstatement to their former positions with full privileges. See Branti v. Finkel, 445 U.S. 507, 509 n.3 (1980). Similar relief has been granted to remedy a constitutionally invalid transfer. See McGill v. Board of Educ. 602 F.2d 774, 776 (7th Cir. 1979). The goal in every case is that "an employee [should be] placed in no worse a position than if he had not engaged in the conduct." Mount Healthy Bd. of Educ. v. Doyle, 429 U.S. 274, 285-86 (1977). In addition, damages may be awarded in appropriate cases. See Simpson v. Weeks, 570 F.2d 240, 243 (8th Cir. 1978), cert. denied, 443 U.S. 911 (1979). 